\title{
Child health in Latin America: historiographic perspectives and challenges
}

\section{Anne-Emanuelle Birn}

Canada Research Chair in International Health; Department of Public Health Sciences, Faculty of Medicine, University of Toronto

155 College St., Room 662

Toronto, ON M5T 3M7 Canada

Phone (416) 946-5792

FAX (416) 978-2087

ae.birn@utoronto.ca
BIRN, Anne-Emanuelle. Child health in Latin America: historiographic perspectives and challenges. História, Ciências, Saúde Manguinhos, Rio de Janeiro, v.14, n.3, p.677-708, July-Sept. 2007.

Patterns of child health and well-being in Latin America's past - have been assumed to be delayed and derivative of European and North Americanexperiences. Through an examination of recent historiography, this essay traces a more complex reality: interest in infant and child health in Latin America arose from a range of domestic and regional prerogatives. This attention was rooted in preColumbian cultures, then relegated to the private sphere during the colonial period, except for young public wards. Starting in the $19^{\text {th }}$ century, professionals, reformers, and policy-makers throughout the region regarded child health as a matter central to building modern societies. Burgeoning initiatives were also linked to international priorities and developments, not through one-way diffusion but via ongoing interaction of ideas and experts. Despite pioneering approaches to children's rights and health in Latin America, commitment to child well-being has remained uneven, constrained in many settings by problematic political and economic conditions uch.

KEYWORDS: child health; infant mortality; child welfare; Latin America.

BIRN, Anne-Emanuelle. Saúde infantil na América Latina: perspectivas historiográficas e desafios. História, Ciências, Saúde Manguinhos, Rio de Janeiro, v.14, n.3, p.677-708, jul.-set. 2007.

Modelos de saúde e bem-estar infantis do passado na América Latina têm sido considerados como subprodutos defasados de experiências européias e norte-americanas. Com base em análise da historiografia recente, este artigo apresenta uma realidade mais complexa: o interesse pela criança e a saúde infantil na América Latina origina-se de um conjunto de condições domésticas e regionais. Com raízes em culturas précolombianas, foi relegado à esfera privada no período colonial, exceto quanto à custódia pública de jovens. A partir do século XIX, profissionais, reformadores e políticos de toda a região passaram a considerar a saúde infantil fundamental para a construção das sociedades modernas. As iniciativas que emergiram desde então guardam relação também com prioridades e programas internacionais, não por difusão unidirecional mas sim pela interação de idéias e especialistas. Apesar das abordagens pioneiras sobre direitos e saúde da criança na América Latina, o compromisso com o bem-estar infantil permanece irregular, e em muitos contextos cerceado por condições políticas

PALAVRAS-CHAVE: saúde da criança; mortalidade infantil; bem-estar da criança; América Latina. 
1 The bibliography here offers a sample of studies and is not intended as an exhaustive survey.
$\mathrm{T}$ he proliferating historical studies of child health in Europe and North America over the past decades have made the need to examine the 'hidden history' of child and infant health and wellbeing in other parts of the world all the more pressing. Latin America offers an extremely useful venue in which to: assess whether the better documented patterns of child and infant health and mortality in modern Europe are generalizable to other settings; gauge the extent to which the colonial period's institutional, social, and cultural legacy has permeated more recent state-building approaches to child health and well-being in different countries of Latin America; and explore the interaction of domestic and international ideas and practices around infant and child health in the late $19^{\text {th }}$ and $20^{\text {th }}$ centuries.

Although the history of infant and child health is rapidly becoming its own subspecialty in the history of medicine and health, scholars of Latin America have, for the most part, viewed child health through other historical lenses: colonial, class, and state power, institutions, and regulation; the formation of social and racial identities and markers; women's public engagement and feminist movements; the building of 'welfare' states and economies; and cultural accounts of childhood. Latin America is, of course, extremely diverse, yet several common themes have shaped the region's responses to the problem of infant and child mortality and health and will serve as an organizational guide to this overview $^{1}$ : pre-Columbian and indigenous heritage; the powerful legacy of colonial class and racial relations, institutions, and practices; an early but incomplete modern state-building effort; considerable engagement with international efforts and movements in the areas of pediatric medicine and public health, social rights, and human welfare.

\section{Pre-Columbian and colonial periods: from child celebration to child circulation}

There is little available historical material concerning child health and well-being in pre-Columbian societies, though anthropological and iconographic studies - as well as various codices and natural histories compiled by Spanish colonists - suggest that birth, reproduction, and child health were important elements of social and religious prestige among indigenous cultures. The Maya, for example, considered children to be a sign of good fortune and paid special attention to infant health (Shein, 1986; Dean, 2002). Aztec children even had their own medical god, Ixtlilton, a deity unknown elsewhere in the world (Shein, 1986). Children were also ritually sacrificed in some Mesoamerican societies, likely a sign of their sacred worth. Various pre-Columbian populations are known for their 
adherence to hygienic precepts, such as bathing rituals following childbirth, testing the milk of wet nurses, monitoring the nursing mother's diet, and for treating ailments with a combination of magic and empiricism (Soustelle, 1970; Bastien, 1996; Fernández Juárez, 2001). Together these measures may account for a life expectancy estimated by some at almost 10 years longer than that of medieval and early-modern Europeans (Ortiz de Montellano, 1990; Viesca Treviño, 1986); others consider pre-Columbian health conditions to have differed little from those in Europe (Alchon, Fall 1997). Historical demographer Robert McCaa, for example, argues that it was high mortality among the Nahua that led to adaptive mechanisms such as infant marriage and complex family structures (McCaa, 1996).

The survival of child health practices and beliefs following Spanish and Portuguese colonial conquest of the region was uneven: some practices and beliefs were lost through population decimation and forced displacement, some were repressed by the colonial state and regulatory apparatus, others survived intact, certain practices were attributed to pre-Columbian cultures (such as the killing of child sorcerers among the Arawak (Santos-Granero, 2002)) even though they were invented only during the colonial period, while still others became part of a syncretic approach to maternal and child health.

For the more than three centuries of Iberian control of what is now Latin America, the footprints of child health and well-being and of children in general - remain mostly hidden (Hecht, 2002). Sonya Lipsett-Rivera (1998) has noted that colonial sources for Latin American childhood tend to be prescriptive rather than descriptive, telling us far more about the values of colonial authorities than the experiences of children's lives. Elizabeth Kuzensof has suggested that the minimal attention to child welfare in this period stems from colonial codes that relegated child-rearing to the private domain, leaving a thin paper trail for scholars (Kuznesof, 2005). Only when children encountered the judicial system through crime and delinquency (Premo, 2000), petitioned royal courts such as the Audiencia of Quito for state protection (Milton, 2004), or became public charges - as foundlings and orphans in charitable or municipal institutions - did they generate records. These records have permitted a growing literature about the most marginal and sickest children, leaving unexamined the lives of the majority of the young during the colonial period.

Children are estimated to have constituted between one third and one half of the population of the Spanish and Brazilian colonies in the Americas by the $18^{\text {th }}$ century; however, even at census time, there were few accurate counts of children, who may have remained undeclared or who were typically included in the same category as 
unwed adults (potentially their own parents!). The routine accounting of births and child deaths is likewise sparse: despite centuries of missionary zeal and the Catholic Church's status as a pillar of Spanish and Portuguese empires, most parish registries for colonial Latin America reveal little detail of the rates or patterns over time of infant and early childhood mortality, except indications that it was staggeringly high, and even moreso among indigenous populations and African-descended slaves, some $80 \%$ of whom failed to reach 5 years of age (Twinam, 1999; Kiple, 1989; Florentino, Góes, 1999; Gaspar, Hine, 1996; Vejarano, 1998).

One of the principal explanations for this incomplete documentation has to do with the elevated rate of illegitimate births in Latin America. In the past (and continuing to the present) up to $50 \%$ of children in some settings were born out of wedlock, as compared to historical rates of illegitimacy in Europe which rarely exceeded $10 \%$ of births. Though illegitimacy fluctuated by race, place, and social class, it was an important feature of virtually every setting of the region. Whether attributed to defiance of colonial authority, the strictures of slavery, cost and effort, cultural irrelevance, alternate patterns of family formation, or the status of women, out-of-wedlock births had significant implications for infant and child survival. As Nara Milanich has shown, colonial law reflected the social opprobrium attached to illegitimacy, yet the legal treatment of illegitimate children varied significantly by whether they were the offspring of adultery or of parents who were technically able to marry. In the former case, children usually lived in matrifocal households, which often faced economic and legal marginalization. Illegitimate children could be enslaved, abandoned, or taken under state tutelage - or they might be rotated among various kin and strangers, forming temporary family-like attachments (Milanich, 2002).

Although illegitimacy did not have universally negative consequences for child health and well-being in Latin America, the greater likelihood of abandonment of illegitimate infants (the literal translation from Spanish for abandoned infants is the 'exposed' [to the elements and to charity] rather than the 'found' (lings) in English) and children undoubtedly resulted in higher rates of mortality. Across colonial Latin America, civil authorities allowed for anonymous abandonment of newborns to foundling homes, often through revolving windows or in hidden alcoves. Formalized abandonment was favored as an alternative to infanticide throughout the colonial period and, in the case of Argentina, until the late $19^{\text {th }}$ century (Ruggiero, 1992). Abandonment was even encouraged in some settings. Colonial authorities favored high fertility among certain indigenous groups in Mexico; elites took in the 'excess' infants and raised them into a separate and 
more docile workforce that competed against other indigenous laborers, thus forcing down wages (Malvido, 1980). Abandonment also increased during epidemics, when, for example, parental deaths in certain parishes of Quito contributed to the abandonment of almost one third of newborns, and even in better times, foundlings (from both married and unmarried parents) constituted one sixth of births (Minchom, 1994).

Since foundling homes and hospitals were Church-run in this period, the surviving records of these institutions offer some evidence of child and infant mortality patterns. In colonial Havana's Casa Joseph, the secret depository system was intended to prevent infanticide, but many foundlings died perhaps even crueler deaths than the babies tossed to sea by desperate mothers. Despite expectation that the religious orders running orphanages would oversee a cadre of wet-nurses and care-givers for their charges, children left at these homes suffered malnourishment, neglect, disease outbreaks, and worse. In the early $18^{\text {th }}$ century, mortality among abandoned children at the Casa Joseph averaged almost $40 \%$ per year, and similar or far higher rates have been documented from institutional registries in Brazil, Argentina, Chile, and elsewhere during the colonial period (González, 2002; Salinas Meza, 1991; Marcílio, 1998; Moreno, 2000; Venâncio, Marcílio, 1999; Venâncio, 1995).

The demand for a legal means of abandoning infants - including among the well-off - kept such institutions open despite appalling track records, mismanagement, and disputes with government authorities. This puzzle of wide public support for 'death sentence' orphanages may be partially explained by the orphanages' key role in providing information about, access to, and even oversight of informal mechanisms for the placement and circulation of children. As has been shown for Chile, Brazil, and other settings, extensive child circulation systems based at orphanages placed parentless children in foster care, as adoptees, and as child servants working in private homes, with their legal status and placement determined by race and social origins (Milanich, 2004; Marcílio, 1993, 1997). For instance, while in the $19^{\text {th }}$ century rates of abandonment and infant mortality increased during times of crisis at Mexico City's house of 'disaffection', few children lived in orphanages for long periods (Malvido, 2004; Martínez Barbosa, 1993).

Of course, child circulation also existed in Europe and elsewhere (Boswell, 1988); perhaps uniquely in Latin America, these practices not only survived as incipient state measures to protect abandoned children were adopted in the region's new Constitutional republics (and the monarchy of Brazil) in the early 19th century, but child circulation networks remained integral to child protection efforts into the 20 $0^{\text {th }}$ century (Blum, 1998; Milanich, 2004). Combined public 
and private means of coping with high illegitimacy and the care of abandoned children through child circulation was thus an enduring child health legacy from the colonial era.

Even before the independence movements of early $19^{\text {th }}$ century Latin America, the colonial regimes of the $18^{\text {th }}$ century began to redefine their relationship and responsibilities to children, with implications for child health and well-being. In Mexico, for example, the moral and social position and trajectories of children under indigenous and early colonial authority were defined before birth by class, race, gender, and legal status, but by the late 1700s the male family head's primary purview over children began to be supplanted by state interest in raising productive citizens (LipsettRivera, 2002). At orphanages this meant enhancing civil status to orphans, regulating the system of wet-nurses who breastfed abandoned infants, and starting in 1804 under orders of the viceroy, vaccinating children against smallpox. The prospect - if not the realization - of state-led child protection efforts thus emerged prior to the region's decolonization.

\section{Nation-building, feminist-maternalism, and the health of the child}

The wave of insurgencies and full-scale war that undulated through Latin America between 1800 and 1825 brought independence to all of the region's Iberian colonies except Puerto Rico and Cuba; continued warfare, political turmoil, and in some settings foreign occupation restricted the contours of state-building. Following decades of instability, the region began to see growth in trade, foreign investment, and economic development in the mid $19^{\text {th }}$ century, yet the social order and agrarian basis of most of the population remained largely unchanged from the colonial period. Moreover, the weak and unstable states of newly independent Latin America typically decentralized political power to local jurisdictions. In child health terms, this situation meant there was little effort to document or address problems, particularly in rural areas.

By the second half of the $19^{\text {th }}$ century, attention to child and social welfare increased in capitals and larger cities, with initially limited participation of most central governments. Since political administrations in this period were often short-lived, charitable and religious agencies - with considerable involvement of middle and upper class women - provided the institutional base and continuity for measures to protect (particularly) urban children from abandonment and destitution in Chile, Argentina, Uruguay and other countries (Lavrin, 1995; Zárate Campos, 1996; Hutchison, 2001). 
The moral discourse around these efforts was framed within an ideological discussion of the building of Latin America's new states in the $19^{\text {th }}$ century followed by the creation of welfare societies in the 20th. Less utilitarian than European empires concerned with productive industrial workers, fit soldiers, and colonial overseers, Latin American interest in child health nonetheless bore a practical side. Political and social elites recognized the importance of child health in the maintenance of order and accepted the role of charitable institutions in jump-starting what might become government welfare roles and responsibilities.

In most Latin American countries, both Conservative Catholic women and middle and upper class liberal women played an important role in maternal and child health advocacy in the $19^{\text {th }}$ and well into the $20^{\text {th }}$ century. Region-wide and national movements for women's equality - ranging from communist to liberal-elite orientations - did not deny femininity and motherhood, but rather embraced these roles. Partly based on Catholic spiritual values, these efforts (also referred to as 'mother-feminism') protested "laws and conditions which threaten[ed women's] ability" to bear children and nurture their families, such as war, drugs, prostitution, urban misery, adultery, and exclusion from suffrage and property ownership (Miller, 1991; Ehrick, 1998; Potthast, Scarzanella, 2001; Molyneux, 2001; Dore, Molyneux, 2000; Zárate Campos, 1999b). In Brazil the abolition movements and pro-motherhood/pro-child health efforts were closely intertwined, with the practice of slave wet-nursing contested by slave women, elite women, folk healers, and doctors (Marko, 2004; Borges, 1992).

As was the case in Europe and North America, Latin American maternalist- feminist movements were most influential in urban settings, where middle class women made social issues part of public policy and mobilized to improve and regulate social conditions for poor children and their mothers. In Argentina, for example, the elite women's voluntary Beneficent Society was a major player in the contentious arenas of social policy and public health starting in the 1820s and for over a century, influencing state assistance to women and children based on a maternalist approach of protection and dependence. In Uruguay, the social assistance societies operated by elite women were less centralized than in Argentina but initially survived the nationalization of public assistance in 1910, becoming purveyors of government-funded services before the full development of the scientific welfare bureaucracy of the state (Ehrick, 2001; Mead, 2000; Potthast, Carreras, 2005). In countries where hospitals and infant asyla were secularized and placed under full or nominal government control early on - for example Mexico starting in the 1860s - women's social assistance efforts, marshaled by activist first ladies, also played a vital part in supplementing 
state activities and transforming child welfare from charity to public benefit (Crispín Castellanos, 1993; Gutiérrez del Olmo, 1993; Betanzos Cervantes, 2004; Buck, 2004).

By the late $19^{\text {th }}$ century, children's health and welfare were appealing issues to public agencies in many countries. During times of longer political stability, such as under the dictatorial rule of Porfirio Díaz in Mexico from 1873-1910 or with the emergence of the Brazilian republic in 1889 (a year after slavery was abolished), the notion of responsibility for molding children into modern citizens was realized by increasingly centralized state institutions intent on controlling delinquency and improving child-raising (Rizzini, 1998; Castillo Troncoso, 1998; Speckman Guerra, 2005). In these settings and far beyond, public welfare agencies began to oversee policies regarding child and social welfare and passed a flurry of juvenile protection measures giving the state new legal powers over family life and displacing responsibility away from the Church and private spheres (Rizzini, Pilotti, 1995; Muñoz, Pachón, 1991; Del Priore, 1999). Not all countries deployed such state power in the name of children's health. In the 1880s, for example, Chilean legislators rejected compulsory smallpox vaccination - in spite of wide agreement that it would lower the nation's deplorable child mortality rates - as a means of limiting Presidential potency (Sater, 2003).

Specific concern with infant mortality as a medical, social, and ultimately political problem emerged in several Latin American countries in the 1870s, almost simultaneous to infant mortality's 'discovery' in Europe and North America. Although, as we shall see, there was at the time little capacity to capture national demographic trends accurately, incipient municipal vital statistics, principally in Latin America's leading cities - as well as data compiled at children's and women's hospitals, asyla and orphanages, charitable agencies, and welfare offices - provided evidence of the severe problem of infant and child deaths and disease (Reyes Londoño, 1997). Earlier in the 19th century, women reformers and charity workers used this information to leverage public and private resources for maternalist assistance and welfare activities. Now their voices were joined by those of male physicians, trained in the new specialty of children's medicine, who had begun to take on formal roles at children's welfare institutions and public health boards (Delgado García, unpublished manuscript). Well aware of - and becoming active participants in - international debates around children's health and welfare, Latin American public health doctors donned demographic hats and began to examine patterns of childhood mortality (Birn, Pollero, Cabella, 2003). With shocking figures of death and misery in hand, physicians joined forces with - or overshadowed - women caretakers of poor children in publicly 
advocating for child health measures. This rhetoric found increasing resonance in political circles but was rarely accompanied by the concomitant resources to combat child misery.

One of the earliest studies of urban infant mortality was undertaken by Dr. Emilio Coni, of Buenos Aires, in 1879 (Plan de trabajo..., 1890; Coni, 1879). Coni, a member of the Buenos Aires City Council before becoming the head of the city's Public Assistance office in 1892, documented disease, injury, vice, and lack of parental guidance among tenement children, then spearheaded legislation protecting children in tenements and the workplace (Recalde, 1988; Coni, 1879). Through these efforts, Coni and many of his fellow doctor-reformers exposed dire social conditions and advocated increased legislative and medical control of the behavior of the poor. The child health movement in Argentina, as elsewhere, incorporated humanitarian, medicalized, and repressive approaches to childraising; at the same time, doctors managed to increase their own social and political prominence, as well as their professional standing.

As Cecilia Muñoz and Ximena Pachón have exemplified for Colombia, most Latin American doctors who analyzed infant mortality patterns in the late $19^{\text {th }}$ century identified two sets of intertwining underlying factors - social misery and maternal ignorance - and called for their improvement through social reform and greater medical and public health attention (Muñoz, Pachón, 1991; Birn, Pollero, Cabella, 2003). Children's ill health - more than high rural or indigenous mortality or workplace death and disease - became a window on the class divide. Other doctors - such as Miguel Mendoza Lopez in the provincial city of Guadalajara, Mexico - followed a more radical social medicine tradition to resolve the infant mortality problem, calling for worker's rights, economic redistribution, and political solutions to redress the extremes of privilege and poverty (Oliver Sánchez, 1986) several decades before the emergence of better known Latin American advocates of social medicine such as Chile's Salvador Allende.

In drawing attention to child health, physicians found themselves at the center of the nationalizing mission. In postslavery Brazil, as Tamera Marko has argued, children - portrayed as future wage-laborers - became the focus of nation-building; pediatricians, in turn, were transformed into new overlords of both worker and national health (Marko, 2004, 2005; Pereira, 2006). Brazil's father-son team Drs. Carlos Arthur Moncorvo de Figueiredo and Arthur Moncorvo Filho were academic towncriers (with 500 publications between them) and tireless advocates of state's accountability for child health and welfare: between the 1870s and the late 1920s, they led a crusade in favor of centralized state control over child welfare institutions. The Moncorvos' systematic push 
for the state's in loco parentis role of safeguarding poor children from the misery and delinquency typical of Brazil's cities was based on an equation of child health and well-being adding up to national health and well-being (Wadsworth, 1999; Wadsworth, Marko, 2001).

Likewise, in Mexico City starting in the late $19^{\text {th }}$ century, juvenile delinquents were moved into vocational schools where they learned a trade and were disciplined in the ways of a hygienic life free of vice and filth. In the same period, day care centers began to be established in the capital for the offspring of single mothers toiling long hours in apparel, cigarette, and other factories, where exercise, nutrition, hygiene, and medical surveillance formed part of overall schooling efforts. The centers - with a continued emphasis on child health and development - became part of the nation's children's welfare system in the wake of the country's 1910-1920 revolution (Vargas Olvera, 1993; Betanzos Cervantes, 2004).

In most places, child-saving measures were more consistent with state-building than social revolution. Brazil's internationallyinspired child-saving movement, Irene Rizzini has demonstrated, put more emphasis on reducing the social threat of delinquents by re-educating them as laborers than on inclusive educational policies which might have reduced Brazil's social inequalities (Rizzini, 2002). Yet in saving children through reform and protectionist measures - even when ambivalently implemented - advocates in Brazil, Venezuela, or Colombia claimed that state-led efforts to improve the moral and work prospects of indigent youth would move these nations into the modern era.

To similar ends, many countries of the region employed school hygiene measures, beginning in the late $19^{\text {th }}$ century and well into the $20^{\text {th }}$, as a symbol of children's importance in the forging of a national identity (Schell, 2004; Morquio, 1929) and the promotion of civility, modernity, and citizenship (Agostoni, 2006). Articulated at Mexico's first Hygienic Pedagogy Congress in 1882, healthy schooling required that school buildings be clean, well-ventilated, supplied with running water or full sanitation systems, and include a gymnasium or other facility for exercise. As Ana María Carrillo (1999) has shown, school medical inspections carried out under the aegis of Mexico's Superior Board of Health were ideally suited to these national goals.

Medical inspections conducted on school premises had the advantage of requiring minimal separate resources or infrastructure compared to other public health activities, and, while the inspections usually revealed severe child health problems such as high rates of tuberculosis (Rodríguez, 1906), school hygiene activities could also be limited to administering smallpox vaccines on site or verifying vaccination certificates for school attendance. Moreover, state 
responsibility was circumscribed to those children who attended school, leaving the vast majority of poor and rural children arguably the sickest - outside of the inspection system. In Panama, for example, despite the symbolic value of children's health in nationalist rhetoric and the practicality of school-based inspections, only a fraction of children were reached until legislation for compulsory school medical service was passed in 1925 (Farinoni, 1986).

In Brazil, Mexico, Uruguay, and other countries, children's health education became the essential counterpart to medical inspection starting in the 1920s and 1930s, with children seen as a conduit to family health (Zioni, Adorno, dez. 1990). School health also captured the interest of international organizations that had hitherto paid little attention to child health. The Rockefeller Foundation's influential International Health Division recognized the importance of these efforts even though it was focused on public health education and disease campaigns rather than child health per se. At São Paulo's Institute of Hygiene in the 1920s, the Rockefeller Foundation actively supported rational school hygiene efforts aimed at the moral, physical, and intellectual regeneration of the primary schoolchild. At Rockefeller-sponsored rural health units in Mexico in the 1930s, nurses and other personnel were encouraged to teach personal hygiene measures to children as a means of inculcating sanitary values across generations (Rocha, 2003; Birn, 1999).

Surfacing at a time of growth and institution-building in the nations of Latin America, child health became a central component of the modernizing agenda that would last over several generations.

\section{Child health takes center stage: puericulture, pan-americanism, and pediatrics}

The child-saving movements that emerged in the late $19^{\text {th }}$ century were fortified after 1900, when the purview of public health boards and departments expanded and national health agencies became one of the pillars of the nascent welfare states of many countries in the region (Márquez, Joly, 1986). Many of the Latin American physicians who advocated for public health and child well-being now had official standing in their own countries and - their prestige boosted by engagement in international conferences, debates, and networks - began to wield considerable policy influence. Physicians and reformers discussed and sometimes partially adopted measures developed overseas, but they also recognized the limits of these approaches amidst conditions of poverty and social disorder. Financial impediments to state action in the early decades of the $20^{\text {th }}$ century meant that feminist reformers and other private sector 
actors continued to play significant roles in child health. As such, the child and maternal health agenda that solidified in these years - including regulation of wet-nursing and adoption, oversight of foundling hospitals, the establishment of children's outpatient and inpatient clinics, pregnancy surveillance, and well-baby care, among other measures (Blum, 1998; Torroella, 1943; Birn, Pollero, Cabella, 2003; Zárate Campos, 1999a; Ungerer, 2000) - arose from a mix of feminist-maternalist ideas, indigenous cultural practices, nationalist concerns, and physician advocacy.

But new developments were also afoot. Late $19^{\text {th }}$ and early $20^{\text {th }}$ century Latin American efforts drew from, coincided with, and shaped both regional and international discussions tying children's health and welfare to the national destiny. At the time, French influences predominated throughout the region in both medical and social welfare domains. In infant and child medical specialties, as in clinical medicine generally, Latin American medical education was modeled on France: French texts were used in classroom training, the most brilliant students went to study in French hospitals and research institutes with the 'masters', and a small but consistent group of elite doctors from throughout the region attended European, and later North American, medical and child health congresses (Castillo Troncoso, 2003; Birn, 2005; Aróstegui, 1889). As in Europe and North America in this period, child health was an area of burgeoning interest within Latin American medicine. Dozens of new positions and departments of child and infant medicine were founded in the 1890s. With wider adoption of the designation of pediatrics circa 1900, the specialty continued its ascendance with national training programs, a new cadre of professional pediatricians, national pediatric associations and congresses, and the founding of the region-wide Archivos LatinoAmericanos de Pediatría in 1905, soon accompanied by a suite of new national pediatric journals (Delgado García, unpublished manuscript).

Engaging with Adolphe Pinard's notion of puericulture (Lefaucheur, 1991; Schneider, 1986) - scientific child-rearing that was both medically-recommended and socially-oriented - Latin American doctors and social reformers also followed the French administrative and juridico-institutional approach to children's welfare, and French standards for infant well-being and maternal protection were widely discussed in Latin American legislatures, policy circles, and professional meetings. For example in the early 1900s, French-style milk stations - gotas de leche-were established by doctors in Uruguay, Argentina, Colombia and other countries, serving as community-based clinics for infant and child health (Muñoz, Pachón, 1991; Rollet, 1997). Although these and other child health and welfare provisions were modeled on the French 
bureaucratic tradition (which had replaced Iberian administrative systems in the $19^{\text {th }}$ century), most Latin American countries never achieved the French ideal of centralized management and policymaking and universality of benefits (Klaus, 1993).

Campaigns for children's health were also magnified by changes in the demographic landscape: sizeable waves of immigrants from Europe, Asia, the Caribbean - and the rural hinterland - to Peru, Brazil, Mexico, Argentina and across the Americas. In many settings immigrants were perceived to be a threat to national aspirations. Political elites in late 19 th and early $20^{\text {th }}$ century Costa Rica, for example, blamed their country's perennial labor shortage on the high infant mortality rate and saw this as the primary reason the country had to resort to accepting Jamaican, Nicaraguan Chinese, and other immigrants believed to be degenerative influences (Palmer, 2003). As such, child health was viewed as a pressure valve on immigration and a precursor to improving the country's racial stock. Indeed, public health and eugenics advocates shared a language of alarm about demography and degeneration with state builders and social reformers (Castillo Troncoso, 2005), making doctors instrumental figures in national modernizing projects.

If eugenics served as an important ingredient in the region's support for maternal and child health, it was also an arena where international disagreements played out. Anglo-Saxon eugenics, as applied in Britain, Scandinavia, North America, and, most infamously, (Nazi) Germany (Broberg, Roll-Hansen, 1997; Weindling, 1992; Barkan, 1992; Mazumdar, 1992; Proctor, 1988; Kevles, 1985; Weindling, 1999; Leon, 2004), was principally informed by Mendelian genetics. Improving a society's genetic stock entailed the breeding out of bad genes through sterilization and prohibitions on procreation (so-called 'negative eugenics'). While such ideas generated divisions among researchers in the United States and elsewhere, the precepts of 'negative eugenics' were successfully translated into social policy, with 31 of 48 U.S. states passing compulsory sterilization laws between 1907 and 1937 (Eugenic News, 1937, p.94).

Eugenics in Latin American countries reflected French approaches more than Anglo-Saxon genetics. As Nancy Stepan has presented for Mexico, Brazil, and Argentina, eugenics was interpreted through neo-Lamarckian ideas about the inheritance of acquired characteristics and implemented through the practices of puericulture and homiculture, the latter a Cuban-coined extension of Pinard's concerns to all age groups. Latin eugenics stressed reforming the social and moral environment of prospective parents and children instead of blocking reproduction. Children raised well might not only overcome an unfavorable genetic background, they would also pass on these new traits to future 
generations, improving the larger society. This so-called 'positive eugenics' movement, with its emphasis on sanitation, health and sound marriage, and the scientific improvement of the circumstances surrounding conception and childhood, closely overlapped with concerns over maternal and child health (Stepan, 1991; Reis, mar.jun. 2000; Sapriza, 2002; Di Liscia, 2005).

The differences between North American and Latin American approaches to eugenics surfaced at the First and Second Pan American Conferences of Eugenics and Homiculture (held respectively in 1927 in Havana and 1934 in Buenos Aires) at which most Latin American delegates rejected the U.S. support for sterilization and the 'improvement' of heredity, favoring instead a focus on bettering home environments and increasing the state's role in social welfare (Stepan, 1991; Guy, July 1998). Yet these divisions did not lead to an abandonment of eugenics in Latin American milieus. Indeed, protecting the health and welfare of children - in contrast to coercive approaches - became the central tenet of Latin American eugenics and facilitated the entry of concepts of eugenics into state policy.

French-influenced Mexican eugenists dominated the Mexican medical establishment and a wide array of government agencies. Education and criminal justice, to mention just two arenas, joined health and medicine in making eugenic ideas central to Mexico's project of national (re)construction following the 1910 Revolution (Stern, 1999, Feb. 1999; Saavedra, 1935). State public health initiatives aimed at children were particularly infused with eugenic thinking. The now-expanded School Hygiene Service closely observed the physical and mental development of school children and the Infant Hygiene Service - under Dr. Isidro Espinosa y de los Reyes's leadership - emphasized puericultural training, home visits, and the medical monitoring of mother and child as a means to reduce infant mortality. Though wide-ranging, such measures were mostly implemented in capitals and larger cities (Miranda, 1930), with rural children neglected by both child health and eugenic activities until the 1930s, or in some cases, until the 1950s or beyond. By comparison, the steps taken by most other governments around the world were more tentative than France's; in Latin America, ambitious state efforts to take on responsibility for infant and child well-being could not be sustained through the existing financial and governing capacity.

Child health also arose as a Latin American priority separate from - though resonant with - European activities. Here eugenic puericulture was one part of an ambitious region-wide effort to bolster the rights, conditions, and health of children which drew from leadership, research, exchanges, and cultural and economic realities of the Americas. Again, public health physicians and 
2 Early Congresses focused on legislative issues (prohibiting the consideration of children as criminals; laws relating to immigration, mandatory schooling, health protection of school children), while subsequent Congresses examined issues from a social perspective, such as eugenics, the causes of family disintegration, children in the workplace, care and education of indigenous children, and the fight against poverty). Later Congresses focused more precisely on the role of government in the well-being of children through social security schemes, social and economic services for poor families, and post-war plans for children, such as libraries, savings institutions, and recreation centers. maternalist feminists spearheaded these movements, competing and partially converging over time. Such Panamerican and Latin American networks were not unique to child health; they formed around topics ranging from medicine and hospitals to housing, sociology, commerce, crime, history, literature, Jews, coffee, highways, electricity, and democracy (kicked off officially by the first International American Conference held in 1889 in Washington, DC), engendering active organizations at both the national and regional level.

In the medical arena, child hygiene and pediatrics enjoyed an increasing presence at the Latin American Medical Congresses, which were inaugurated in Santiago de Chile in 1901 and had a special child medicine section by the $5^{\text {th }}$ region-wide meeting in Lima in 1913 (Almeida, 2003). In public health circles, it took somewhat longer for children's health to gain attention. In December 1902 the International Sanitary Bureau (as of 1923 known as the Pan American Sanitary Bureau [PASB], and as the Pan American Health Organization [PAHO] starting in 1958) was founded in Washington with the support of the U.S. and 10 Latin American countries, eventually reaching the membership of all of the republics of the region. Physician representatives to the quadrennial conventions began expressing their concerns with childhood illness and high infant mortality starting in 1907 (Ulloa et al., 1910) and demanded that maternal and child health become part of the bureau's official agenda following World War I. However, the US-dominated bureau - with its priorities focused on the protection of commerce from epidemic outbreaks and the development of a Pan American Sanitary Code - took almost 30 years to respond to the beleaguered efforts of Latin American delegates to highlight child health concerns (Birn, 2002). Meanwhile, women reformers and child health advocates and reformers took their organizing elsewhere.

In the wake of two aborted efforts to institutionalize an international association for childhood protection in Brussels (in 1907 and 1913), a group of Latin America 'maternalist feminists', who viewed the lot of children to be inextricably linked to the rights of women as mothers, organized the first Pan American Child Congress in Buenos Aires in 1916. The meetings and the larger movement served for almost half a century as a vibrant hemispheric forum for Latin American reformers, feminists, nurses, policy makers, sociologists, physicians, lawyers, and social workers devoted to improving the health and welfare of poor and working class children and their mothers (Conferencias..., 1943). ${ }^{2}$ The eight congresses that met between 1916 and 1942 influenced the passage of dozens of laws protecting children and their mothers delineating children's rights in such areas as adoption, infant health, and child 
labor and the implementation of a mix of public and private measures (Guy, July 1998; Ehrick, 1998) and helped generate similar efforts internationally at the League of Nations through Uruguay's Dr. Paulina Luisi and other South American delegates who had been involved in the congresses before heading to Geneva (Scarzanella, 2001).

By the time of the second congress held in 1919 in Montevideo, pediatricians had upstaged feminist reformers. In 1927 the Child Congress organizers' decade-long dream of founding a permanent Instituto Internacional Americano de Protección a la Infancia (International Institute for the Protection of Childhood) was realized in Uruguay, with the support of the League of Nations. The first of its kind in the world, the Institute collected and disseminated research and policy information pertaining to the care and protection of mothers and children. Its widely-circulated journal, library, health education materials, and the subsequent Child Congresses it organized rapidly established a strong reputation for the Institute and generated a large network of informants and collaborators throughout the region and the world.

From the late 1920s until the 1940s the Institute - with Uruguay serving as a policy incubator - pioneered innovative social legislation relating to the health and welfare of children under the leadership of Uruguayan pediatrician Dr. Luis Morquio and others. In 1934 Uruguay passed a Children's Code that spelled out children's rights to health, welfare, education, and decent living conditions, and which created specific centralized institutions to run and oversee child and maternal aid programs. Morquio and his colleagues were frequently invited to share their research and policy ideas with Europeans, serving as exporters, as well as importers, of childhood - related scientific theory and practice. The Boletín del Instituto Internacional Americano de Protección a la Infancia became a leading venue for comparative child health and child policy, with an array of international experts covering worldwide child health issues. The League of Nations Health Organization sponsored several of the Institute's infant mortality and nutrition studies, and Institute director Morquio was named President of Geneva-based Save the Children in 1930 (Birn, 2006b).

Encouraged by mutual interests and the cross-fertilization of ideas through the Child Congresses and the Institute, many countries began to hold national child conferences and set aside a day or week of the child (Día del Niño) to draw attention to matters of child health and social welfare and to generate wider support for the development of centralized institutions and legal protections for child health and welfare. In the 1930s, some countries, such as Chile, established extensive maternal and child health measures, including several months of paid maternity leave, an allowance 
for nutrition and infant health services, and exclusive infant access to maternal milk until age five. By 1940 most of the region's republics, including Argentina, Bolivia, Brazil, Chile, Colombia, Costa Rica, Cuba, Ecuador, Mexico, Nicaragua, Paraguay, and Venezuela had specific bureaus or agencies dedicated to maternal and child health protection (García, 1981; Márquez, Joly, 1986; MesaLago, 1985).

While these bureaus are mentioned in various institutional histories (Amézquita Alvarez et al., 1960) there remains much to be analyzed about such national efforts as well as the movements and influences that existed outside the public sector. For example, the Rockefeller Foundation's international health activities in Latin America in the first half of the $20^{\text {th }}$ century, though not aimed specifically at maternal and child health, entered this arena through involvement in nursing and graduate public health education, rural health, and the forerunner of its later family planning efforts (Black, 2002; Birn, 2006a; Vessuri, set.-dez. 2001). In most settings growing national attention to child health in the 1930s and 1940s did not exclude competing ideologies and approaches. In Argentina and other countries with a strong Church, the development of a children's welfare state did not part with the moralistic teachings of Catholicism but incorporated values of family moralism and marriage as a means of decreasing illegitimacy and improving fertility and child health (Di Liscia, 2002). Revolutionary maternalism in Mexico was interlaced with growing medicalization and state control over mothering practices (Blum, 2003), yet the diffusion of eugenic puericulture beliefs and practices necessarily took place through religious, civil society, and private channels.

In the first half of the $20^{\text {th }}$ century the proliferation of Pan Americanism played an important part in framing regional approaches to child health in scientific, cultural, political, and legal terms. Notwithstanding powerful nationalistic rhetoric and the persistent advocacy and region-wide solidarity of professionals and reformers, however, a full-blown child-centered welfare state was perennially impeded by difficult political and economic conditions, leaving an ongoing role for private action (Guy, 2002; Blum, 2001).

\section{Demographic perspectives and the international context}

Another angle on child health in Latin America in the republican period comes from nascent studies in historical demography. Typically following French bureaucratic templates, a few countries, some states and provinces, and many capital cities and other municipalities in the region began to collect statistics and study demographic trends starting in the late $19^{\text {th }}$ or early $20^{\text {th }}$ century. 
Peru and Mexico passed vital statistics legislation in the 1850s, Argentina founded its Civil Registry in 1871, Uruguay in 1879, and Brazil followed suit in 1888. More sporadic than systematic, and capturing far more urban than rural demographics, these registries nonetheless revealed extremely high infant mortality rates throughout the region (Mitchell, 2003). Demographers have pointed out that in most settings there was significant underregistration of births (especially for illegitimate births and those in poor and isolated households), as well as extreme under-reporting of infant deaths in the early hours, days, or months of life (McGuire, Frankel, 2005), suggesting that uncorrected mortality figures are unreliable. Certainly, as discussed above, these figures served as ammunition in contentious debates over depopulation, fitness for employment, and racial, ethnic, and national identity.

Yet important as these data were in fueling contemporary discussions, they have been of limited use for historians interested in analyzing prewar national patterns. For example, though Buenos Aires data began to be compiled in the 1850s and were relatively complete by the 1870s (Mazzeo, 1993), and statistical

\footnotetext{
“El Torno,” anonymous child abandonment turnstile at Montevideo's orphanage. Caption translates: "My mother and father tear me from themselves; divine charity takes me in here."

Courtesy of Sociedad Uruguaya de Pediatría
}

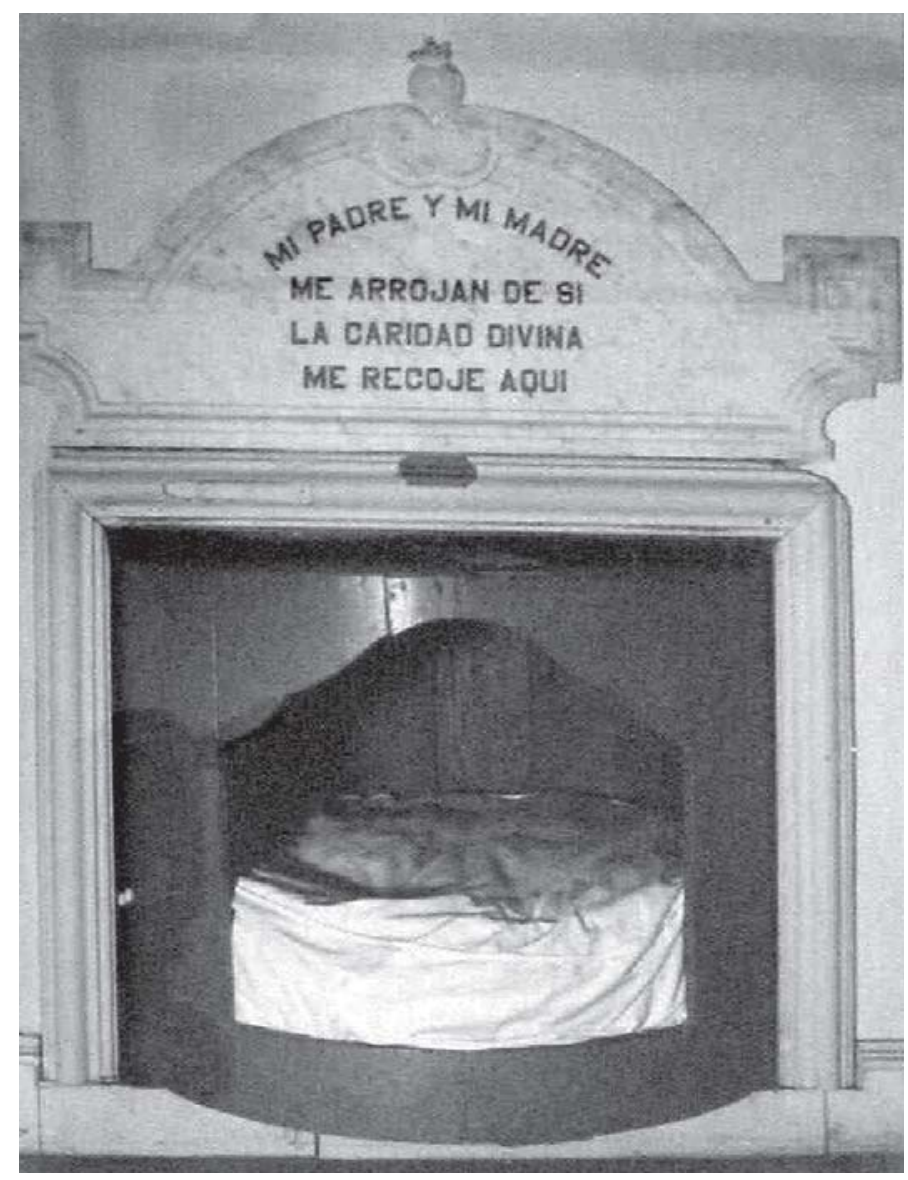


annuals covering Brazilian state capitals and regions began sporadic publication in 1894, neither Argentina nor Brazil compiled reliable national-level records until the 1940s (Brasil, 1999). Peruvian and Mexican registries, as in most Latin American countries, did not achieve national coverage until the 1950s (Hakkert, 1996). Uruguay's Civil Registry with regular national coverage by the 1880 s and infant mortality data available from the 1890s, serves as an exception to this timing; ironically, Uruguay's scarce censuses makes infant (and child) mortality more reliable than adult mortality, for which a population denominator is difficult to ascertain (Rial, 1980; Pellegrino, 1997).

The paucity and deficiencies of Latin American vital statistics data from before World War II make demographic analyses of child and infant mortality in the region challenging. In some cases, there are municipal or regional mortality series starting around 1900 that allow for partial mortality analyses by age and or by cause (covering leading childhood ailments such as diarrhea or respiratory infections) in settings such as Buenos Aires, Santiago de Chile, Rio Grande do Sul (Brazil), Tandil (Argentina), Medellín, and Rio de Janeiro (Cuadro..., 1901; Alvarez, Miguez, 1989; Bonow, 1979; Celton, 1998; Reyes Londoño, 1997; Antunes, Apr. 1998; Cavalcanti, 1988; Alves, 2001). Scholars have begun to examine a series of surveys sponsored by the League of Nations Health Organization (LNHO) in the late 1920s which provided detailed assessments of the specific and underlying causes of infant mortality in four South American countries (Argentina, Brazil, Chile, and Uruguay) comparable to LNHO studies sponsored in Europe (Debré, Olsen, 1931; Campbell, 1929; Scarzanella, 2003). Other local studies examine the role of labor patterns, social structure, land tenure, production and export, and hunger on infant mortality (Puerto, 2004).

The most closely examined case of infant and child health comes from Uruguay, where infant mortality circa 1900 was lower than that of all recorded countries except Norway but then fluctuated around the same level for almost four decades, whilst other countries experienced sustained declines. In all likelihood, it was Uruguay's early successes in this arena that initially left child well-being out of its early welfare state measures. The regularization of public health services, the monitoring of milk, water supply and sewage, regulation of tenements, the implementation of the Children's Code of 1934, as well as the introduction of specific diarrhea control measures and a family wage in the 1940s all contributed to the eventual improvements in Uruguayan infant mortality (Birn, forthcoming).

Uruguay's infant mortality conundrum, as well as a recent comparison of Montevideo and Buenos Aires pointing out that 
Buenos Aires infant mortality declined faster than that of Montevideo in the first decades of the $20^{\text {th }}$ century in spite of Uruguay's greater centralization and welfare orientation (Mazzeo, Pollero, 2005) suggest that Latin American child health patterns differ from the more studied cases of Europe not only in timing, but also in levels, causes, and approaches. A recent study of mortality in early $20^{\text {th }}$ century Cuba also points to tailored public health measures - as a form of policy one-upmanship between political parties - may have been a far more important determinant of infant mortality than the combined effects of economic growth, changes in the standard of living, and maternal hygiene cited in the European context (McGuire, Frankel, 2005).

Undoubtedly only the beginning of child-specific demographic perspectives on Latin American health, these studies defy the diffusionist characterizations of historical studies of development and child health.

\section{From the private sphere to the welfare state, and back?}

The late $19^{\text {th }}$ and early $20^{\text {th }}$ century served as a watershed for children's health policy in Latin America. In the process of forging modern identities and societies amidst the challenges of immiseration, immigration, urbanization, and social disorder, state

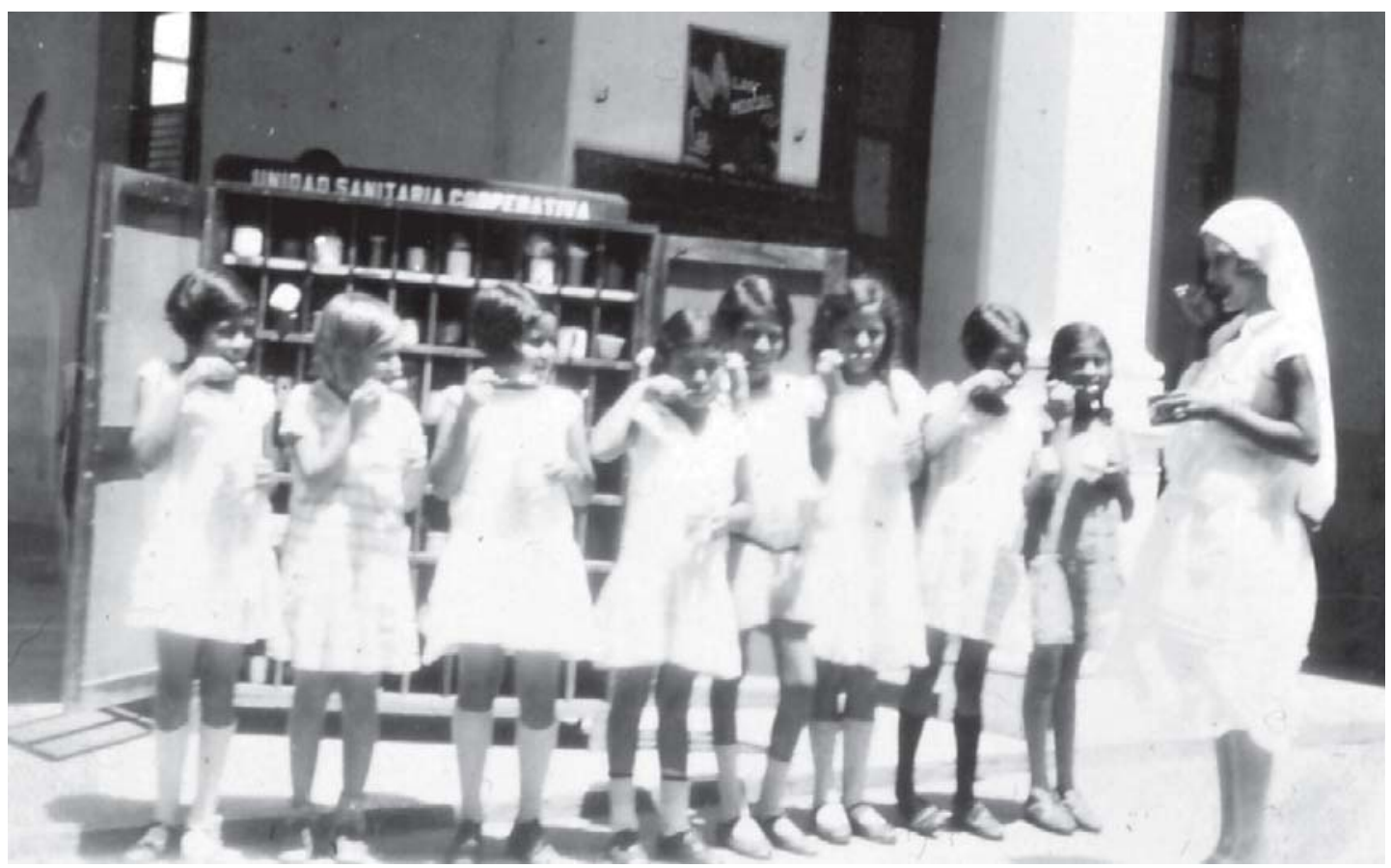

Schoolgirls brushing their teeth, with cubby holes for toothbrush storage at Rockefeller Foundation-Mexican Health Department cooperative health unit in rural Mexico. Courtesy of the Rockefeller Archive Center 
interests recognized and began to address the problems of child health, which had long been relegated to the private domain. Women social reformers, medical professionals, and other advocates served as active policymakers and purveyors of child health measures domestically and interacted with Latin American and other international counterparts. Mindful of national imperatives and foreign developments, Latin Americans ideas and activities also circulated overseas, with these interchanges reaching a crescendo in the interwar period.

If the over-arching framework of Latin American attention to maternal and child health by the 1920s and 1930s was of state institution-building, it was inevitably an arrested effort. In contrast to Skocpol's portrayal of a transition from maternalism to state paternalism in the U.S. (Skocpol, 1992), Donna Guy points to a more complex history. Public policies for children were central to the rise of the Latin American welfare state, but children's welfare remained a hybrid of public paternalism and private maternalism. Because the welfare state was never all-encompassing in Latin America, the mix of both private and institutional responses to child health and well being (state, medical, and charitable) have remained characteristic of the region (Guy, 2001).

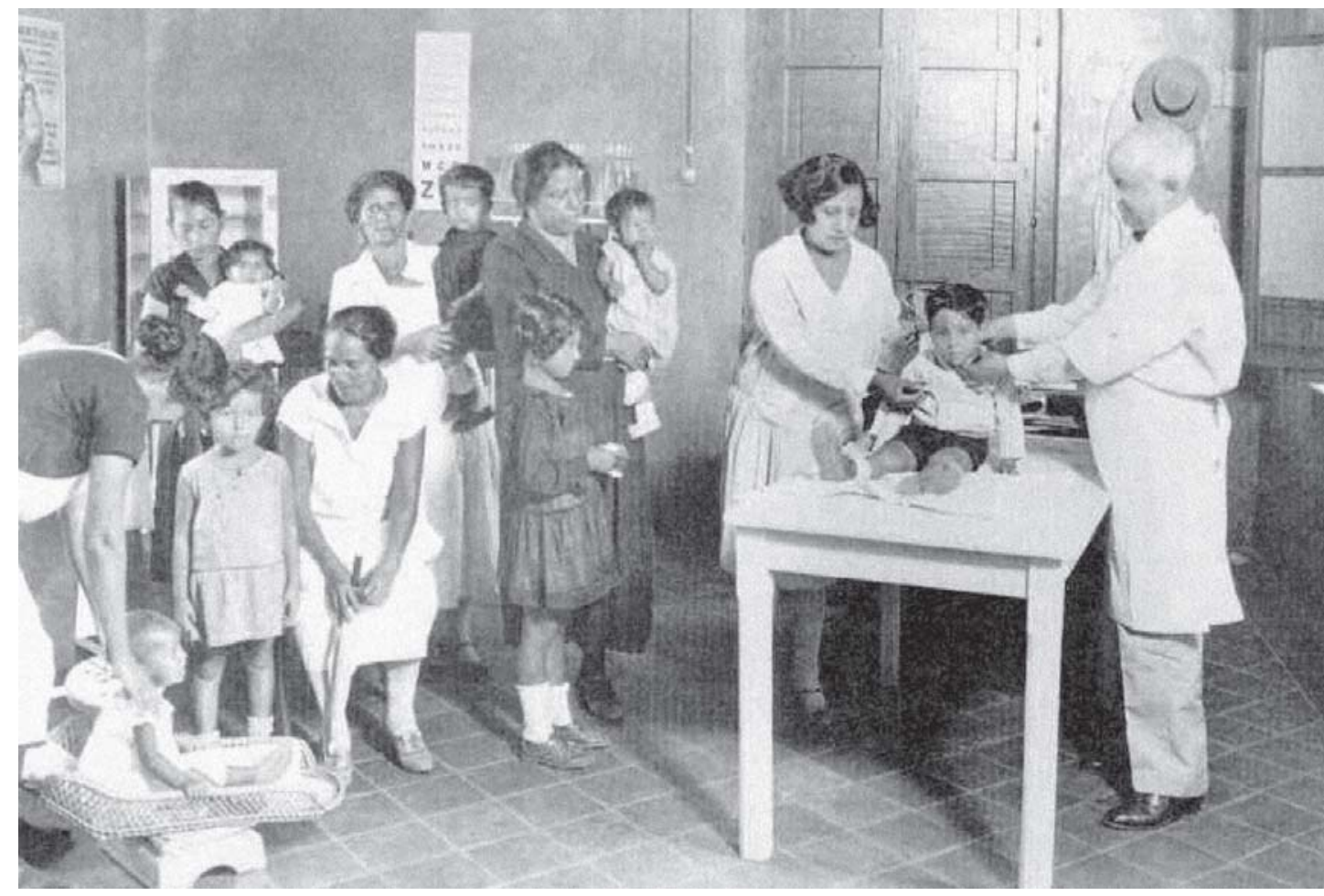

Mothers and children attending Infant Hygiene Clinic at Veracruz health unit, 1929. Courtesy of the Rockefeller Archive Center 
It is important to note that the factors shaping child health policy in Latin America - French models and international interactions, eugenics, maternalist reformers and pediatricians, and statebuilding forces - have for the most part been examined from an urban viewpoint, inevitably masking other perspectives. Studying welfare state measures may lead rural-urban differences, indigenous populations, and the historical legacy of slavery and persistent hierarchies of race to be overlooked. For example, despite Brazil's race-myth of harmony there are and were persistent infant and child mortality - and social welfare - differences along a racial continuum, even when controlling for socioeconomic factors (Sowards, 1993; Wood, Lovell, 1992; Maio, Santos, 1996).

The end of World War II marks a breakpoint for the history of children's health - and the endpoint for this analysis - for a number of reasons. Within the region, the children's rights movement culminated in the 1948 Pan American Children's Code, co-authored by the Instituto Internacional Americano de Protección a la Infancia, the PASB, and the U.S. Children's Bureau. Signed at the Ninth Pan American Child Congress held in Caracas in 1948, the Code stipulated that:

all measures necessary must be taken in order to assure that all children, regardless of race, color, or creed, enjoy the best health conditions, based on adequate hygiene, together with the necessary good housing, sun, air, cleanliness, and clothing in order that they may benefit from the opportunity to live healthy, happy, and peaceful lives (Opas, 1948).

Like Latin American child health measures in general, the Pan American Children's Code drew from and influenced both local and international sources. It incorporated some principles from Save the Children founder Eglantyne Jebb's Declaration of the Rights of the Child - adopted by the League of Nations in 1924 while other principles derived directly from Uruguay's Code adopted in 1934. Moreover, the Pan American Code, with its advocacy for all the ingredients of child well-being, inspired subsequent international children's rights efforts, particularly the 1989 Convention on the Rights of the Child.

While the recent history of Latin American social policy is one of persistent gaps among passage, implementation, and enforcement of social protection policies and legislation, the Children's Code nonetheless marked a new era in the recognition of the support for children's health and welfare as a state responsibility. The development of vital statistics capacity in almost all countries of the region also meant that children's well-being could now be monitored through routine demographic analysis. 
Acknowledgements

Thanks to Kristin Ruggiero for her helpful comments and to George Weisz, Cynthia Comacchio, and Janet Golden, who co-organized the colloquium that inspired this article: Comparative and Interdisciplinary Approaches to Child Health in the $20^{\text {th }}$ Century, McGill/ McCord/AMS Colloquium, held in Montreal in October 2004. I am also grateful to Sarah Stranks for the preparation of references. Funding for the research and writing of this paper was provided by the Canada Research Chairs Program.
Following World War II, changes at the international level brought a new spotlight to children's health in Latin America and other developing regions. Newly founded UN agencies, particularly the WHO and Unicef, put maternal and child health high on their agendas (Gillespie, 2003). As the problems of European refugees were resolved, these agencies concentrated on fighting poverty (and Communism) in developing countries, leaving less room for the interplay of child health ideas and practices to and from Latin America as had transpired in the previous period. The proliferation of bilateral agencies and nongovernmental organizations in the context of the Cold War turned health cooperation into an ideological tool with Latin America as contested terrain. With a growing technical armamentarium, including vaccines, antibiotics, contraceptives, and later oral rehydration therapy, international agencies became deeply involved in the promotion and delivery of children's health services as part of population control and 'child survival' strategies. Ironically, the region's most successful models of child health improvement in the postwar era - those of Cuban socialism and Costa Rica's multi-pronged approach of nutrition programs, the abolition of the military, and social redistribution drew far more from domestic welfare policymaking than from international aid (Morgan, 1990).

Although the history of child health in Latin America - amidst its diversity - may be summarized as one of a never fully realized ideal of state responsibility for social welfare, the emerging literature discussed in this historiographic essay portrays the countries of the region confronting the problem of child health amidst a constellation of legacies, constraints, and influences. Over time child health ideologies, institutions, and practices drew successively and sometimes simultaneously from indigenous traditions, colonial patterns, state-building concerns, technical developments, racial and medical ideologies, and domestic and international innovations. Far from being derivative of outside efforts, the region's child health approaches interacted with broader tendencies and movements while being forged locally - and in turn reverberated widely.

\section{REFERENCES AND BIBLIOGRAPHY}

Agostoni, Claudia 2006

Alchon, Suzanne Austin Fall 1997

Almeida, Marta de 2003
Popular health education and propaganda in times of peace and war in Mexico City, 1890s-1920s. American Journal of Public Health, Washington (DC), v.96, p.52-61.

The great killers in Precolumbian America: A hemispheric perspective. Latin American Population History Bulletin, Minneapolis, n.27.

Persectivas sanitárias e representações médicas nos congressos médicos latino-americanos (1901-1913). Horizontes, Bragança Paulista, v.21, p.37-47. 
Alvarez, Norberto;

Miguez, Eduardo

1989

Alves, Florentina 2001

Amézquita Alvarez, Jose et al. 1960

Antunes, José Leopoldo Ferreira

Aróstegui, Gonzalo 1889

Barkan, Elazar 1992

Bastien, Joseph 1996

Betanzos Cervantes, Irma 2004

Birn, Anne-Emanuelle 2006a

Birn, Anne-Emanuelle $2006 b$

Birn, Anne-Emanuelle 2005

Birn, Anne-Emanuelle 2002

Birn, Anne-Emanuelle 1999

Birn, Anne-Emanuelle (forthcoming)

Birn, Anne-Emanuelle;

Pollero, Raquel;

Cabella, Wanda

2003

Black, Victoria Lynn 2002

Blum, Ann S. 2003
Morir en la frontera: patrones de mortalidad en las tierras nuevas de la provincia de Buenos Aires - Tandil (1860-1895). Siglo XIX Revista de Historia, Monterrey (Mexico), v.4, n.7, p.9-70.

A mortalidade infantil e as práticas sanitárias na cidade de São Paulo,1892-1920. Dissertação (Mestrado em História Social) - Universidade de São Paulo, São Paulo.

Historia de la salubridad y de la asistencia en México. v.4. Mexico (DF)

Secretaría de Salubridad y Asistencia.

'Grow and multiply': social development, birth rates and demographic transition in the municipality of São Paulo, Brazil, time-series for 1901-94. Revista Brasileira de Epidemiologia, São Paulo, v.1, n.1, p.61-78. Apr. 1998

Enfermedades de la infancia.

Habana: Imprenta del Ajustador Comercial

The retreat of scientific racism: changing concepts of race in Britain and the United States between the World Wars. New York: Cambridge University Press.

La Montaña del Cóndor: metáfora y ritual en un Ayllu andino.

La Paz: Hisbol.

Escuelas Casa Amiga de la Obrera: una institución de asistencia para la infancia. In: México. Dirección General de Atención Materno Infantil. La atención materno infantil: apuntes para su historia. México (DF): Secretaría de Salud. p.147-167.

Marriage of convenience: Rockefeller international health and revolutionary Mexico. Rochester (NY): University of Rochester Press.

O nexo nacional-internacional na saúde pública: o Uruguai e a circulação das políticas e ideologias de saúde infantil, 1890-1940. História, Ciências, Saúde - Manguinhos, Rio de Janeiro, v.13, n.3, p.227-260.

Uruguay on the World stage: how child health became an international priority. American Journal of Public Health, Washington (DC), v.95, n.9, p.1506-1517.

No more surprising than a broken pitcher?: maternal and child health in the early years of the Pan-American Sanitary Bureau. Canadian Bulletin of Medical History, Halifax, v.19, n.1, p.17-46.

Skirting the issue: women and international health in historical perspective. American Journal of Public Health, Washington (DC), v.89, n.3, p.399-407.

Doctors on record: Uruguay's infant mortality stagnation and its remedies, 1895-1945. Bulletin of the History of Medicine, Baltimore.

No se debe llorar sobre leche derramada: el pensamiento epidemiológico y la mortalidad infantil en Uruguay, 1900-1940. Estudios Interdisciplinarios de América Latina, Tel Aviv, v.14, n.1, p.35-65.

Taking care of baby: chilean state-making, international relations and the gendered body politic, 1912-1970. Dissertation (Philosophical Doctor) University of Arizona, Tucson.

Dying of sadness: hospitalism and child welfare in Mexico City, 1920-1940. In: Armus, Diego (Ed.). Disease in the history of modern Latin America: from malaria to AIDS. Durham: Duke University Press, p.209-236. 
Blum, Ann S. 2001

Blum, Ann S. 1998

Bonow, Germano Mostardeiro 1979

Borges, Dain 1992

Boswell, John 1988

Brasil 1999

Broberg, Gunnar; Roll-Hansen, Nils 1997

Buck, Sarah 2004

Campbell, Dame Janet Mary 1929

Carrillo, Ana María 1999

Castillo Troncoso, Alberto del 2005

Castillo Troncoso, Alberto del 2003

Castillo Troncoso, Alberto del 1998

Cavalcanti, Nicanor Ferreira 1988

Celton, Dora E. 1998

Conferencias... 1943

Coni, Emilio R. 1879
Conspicuous benevolence: liberalism, public welfare, and private charity in Porfirian Mexico City, 1877-1910. The Americas, Baltimore, v.58, n.4, p.7-38.

Public welfare and child circulation, Mexico City, 1877 to 1925 . Journal of Family History, Ottawa, v.23, n.3, p.240-271.

Indicadores de saúde no Rio Grande do Sul: aspectos históricos, 1900-1977. Dissertação (Mestrado em Saúde Pública) - Universidade de São Paulo, São Paulo.

The Family in Bahia, Brazil, 1870-1945.

Stanford: Stanford University Press.

The kindness of strangers: the abandonment of children in Western Europe from Late Antiquity to the Renaissance. New York: Pantheon Books.

Brasil. IBGE. Departamento de População e Indicadores Sociais. Evolução e perspectivas da mortalidade infantil no Brasil.. Rio de Janeiro: IBGE. (Estudos e Pesquisas. Informação Demográfica e Socioeconômica, 2.)

Eugenics and the welfare state: sterilization policy in Norway, Sweden, Denmark, and Finland. Lansing: Michigan State University Press.

Women and social welfare (Mexico). In: Herrick, John M.; Stuart, Paul H. (Ed.). Encyclopedia of social welfare history in North America. Thousand Oaks: Sage Publications, p.444-447.

Infant mortality: inquiry of the Health Organisation of the League of Nations, English Section, report. Statistical notes by Peter L. McKinlay. London: H.M. Stationery Office.

El inicio de la higiene escolar en México: Congreso Higiénico Pedagógico de 1882. Revista Mexicana de Pediatría, México (DF), v.66, n.2, p.71-74.

Médicos y pedagogos frente a la degeneración racial: la niñez en la ciudad de México, 1876-1911. In: Agostoni, Claudia; Speckman Elisa (Ed.). De normas y transgresiones: enfermedad y crimen en América Latina (18501950). México (DF): Instituto de Investigaciones Históricas/Universidad Nacional Autónoma de México. p.83-107.

La visión de los médicos y el reconocimiento de la niñez en el cambio del siglo XIX al XX. Boletín Mexicano de Historia y Filosofía de Medicina, México (DF), v.6, n.2, p.10-16.

Entre la criminalidad y el órden cívico: Imágenes y representaciones de la niñez durante el Porfiriato. Historia Mexicana, México (DF), v.48, n.2, p.277-320.

Condições de vida e mortalidade infantil no estado de São Paulo: uma abordagem socioeconômica. Dissertation (Master of Arts) - Pontifícia Universidade Católica de São Paulo, São Paulo.

Enfermedad y crisis de mortalidad en Córdoba, Argentina, entre los siglos XVI y XX. In: Celton, Dora E.; Miró, Carmem; Sánchez Albornoz, Nicolás (Org.). Cambios demográficos en América Latina: la experiencia de cinco siglos. Córdoba: Universidad Nacional de Córdoba; International Union for the Scientific Study of Population (IUSSP).

Conferencias Internacionales Americanas: primer suplemento 1938-1942. Washington (DC): Carnegie Endowment for International Peace.

La mortalidad infantil en la ciudad de Buenos Aires: estudio comparativo con la mortalidad infantil de Río de Janeiro, Montevideo, Lima, México y otras ciudades americanas. Buenos Aires: Imprenta de Pablo E. Coni. 
Crispín Castellanos, Margarito 1993

Cuadro.. 1901

Dean, Carolyn 2002

Debré, Robert; Olsen, E.W. 1931

Delgado García, Gregorio unpublished

Del Priore, Mary (Ed.) 1999

Di Liscia, María Silvia 2005

Di Liscia, María Silvia 2002

Dore, Elizabeth; Molyneux, Maxine 2000

Ehrick, Christine 2001

Ehrick, Christine Nov. 1998

Eugenic News 1937

Farinoni, Noemi 1986

Fernández Juárez, Gerardo 2001

Florentino, Manolo; Góes, José Roberto de 1999

García, Juan Cesar 1981

Gaspar, David Barry; Hine, Darlene Clark 1996
Hospital de Maternidad e Infancia: una perspectiva histórica de un centro de beneficencia pública de fines del siglo XIX. In: México. Secretaría de Salud. Dirección General de Atención Materno Infantil. La atención materno infantil: apuntes para su historia. México (DF): Secretaría de Salud. p.95-115.

Cuadro comparativo de los expósitos en Buenos Aires, Río de Janeiro, Santiago de Chile, y Montevideo. Revista Médica del Uruguay, Montevideo, v.4, n.6, p.227.

Sketches of childhood: children in colonial Andean art and society. In: Hecht, Tobias (Ed.). Minor omissions: children in Latin American history and society. Madison: University of Wisconsin Press. p.21-51.

Société des Nations. Organisation d'Hygiène. Les enquêtes entreprises en Amérique du Sud sur la mortalité infantile. Boletín del Instituto Internacional Americano de Protección a la Infancia, Montevideo, v.4, n.3, p.581-605.

La cátedra de Patología y Clínica Infantiles de la Facultad de Medicina de la Universidad de La Habana (1899-1962). In: Delgado García, Gregorio. Historia de la enseñanza superior de la medicina en Cuba (1900-1962).

História das crianças no Brasil.

São Paulo: Contexto.

Colonias y escuelas de niños débiles: los instrumentos higiénicos para la eugenie. Argentina, 1910-1945. In: Di Liscia, María Silvia; Boholavsky, Ernesto (Ed.). Instituciones y formas de control social en América Latina, 1840-1940: una revisión. Buenos Aires: Prometeo. p.93-113

Hijos sanos y legítimos: sobre matrimonio y asistencia social en Argentina (1935-1948). História, Ciéncias, Saúde - Manguinhos, Rio de Janeiro, v.9, supl., p.209-232.

Hidden histories of gender and the State in Latin America.

Durham: Duke University Press, p.33-81.

Affectionate mothers and the colossal machine: feminism, social assistance and the State in Uruguay, 1910-1932. The Americas, Baltimore, v.58, p.121-139. 2001

Madrinas and missionaries: Uruguay and the Pan-American Women's Movement. Gender $\mathcal{E}$ History, Ann Arbor, v.10, n.3, p.406-424.

Eugenic News.

New York, v.22, p.94.

El valor social de la niñez y la atención de la salud-enfermedad (1903-1930). Revista del Hospital del Niño, Panamá, v.5, n.1, p 55-59.

Testimonio Kallawaya, medicina indígena en la ciudad de La Paz (Bolivia). Asclepio, Madrid, v.53, n.1, p.245-280.

Crianças escravas, crianças dos escravos. In: Del Priore, Mary (Ed.). História das crianças no Brasil. São Paulo: Contexto. p.177-191.

La medicina estatal en América Latina, 1880-1930. Revista Latinoamericana de Salud, México D.F., v.1, p.73-104.

More than chattel: black women and slavery in the Americas. Bloomington: Indiana University Press. 
Gillespie, James

2003

González, Ondina 2002

Gutiérrez del Olmo, José Felix Alonso 1993

Guy, Donna 2002

Guy, Donna 2001

Guy, Donna July 1998

Hakkert, Ralph 1996

Hecht, Tobias 2002

Hutchison,

Elizabeth Quay 2001

Kevles, Daniel J. 1985

Kiple, Kenneth F. 1989

Klaus, Alisa 1993

Kuznesof, Elizabeth Anne 2005

Lavrin, Asunción 1995

Lefaucheur, Nadine 1991

Leon, Sharon M. 2004

Lipsett-Rivera, Sonya 2002

Lipsett-Rivera, Sonya 1998

Maio, Marcos Chor; Santos, Ricardo

Ventura (Org.) 1996
International organizations and the problem of child health, 1945-1960. Dynamis, Granada, v. 23, p.115-142.

Down and out in Havana: foundlings in eighteenth century Cuba. In: Hecht, Tobias (Ed.). Minor omissions: children in Latin American history and society. Madison: University of Wisconsin Press. p.102-113.

De la caridad a la asistencia: un enfoque de la pobreza y la marginación en México. In: México. Dirección General de Atención Materno Infantil. La atención materno infantil: apuntes para su historia. México (DF): Secretaría de Salud. p.9-51.

The State, the family, and marginal children in Latin America. In: Hecht, Tobias (Ed.). Minor omissions: children in Latin American history and society. Madison: University of Wisconsin Press. p.139-164.

Editor's Page.

The Americas, Baltimore, v.58, p.1-6.

The Pan American Child Congresses, 1916 to 1942: pan americanism, child reform, and the welfare state in Latin America. Journal of Family History, Ottawa, v.23, n.3, p.272-291.

Fontes de dados demográficos. Belo Horizonte: Associação Brasileira de Estudos Populacionais.

Minor omissions: children in Latin American history and society. Madison: University of Wisconsin Press.

Labors appropriate to their sex: gender, labor, and politics in urban Chile, 1900-1930. Durham: Duke University Press.

In the name of eugenics: genetics and the uses of human heredity. New York: Alfred A. Knopf.

The nutritional link with slave infant and child mortality in Brazil. Hispanic American Historical Review, Pittsburg, v.69, n.4, p.677-690.

Every child a lion: the origins of maternal and infant health policy in the United States and France, 1890-1920. Ithaca (NY): Cornell University Press.

The house, the street, global society: Latin American families and childhood in the twenty-first century. Journal of Social History, Fairfax, v.38, n.4, p.859-872.

Women, feminism, and social change in Argentina, Chile, and Uruguay. Lincoln: University of Nebraska Press.

La puériculture d'Adolphe Pinard. In: Manciaux, M. ; Rimbault, G. (Ed.). Enfances menacées. Paris: Ed. de l'INSERM.

Hopelessly entangled in Nordic pre-suppositions: Catholic participation in the American Eugenics Society in the 1920s. Journal of the History of Medicine and Allied Sciences, Oxford (UK), v.59, p.3-49.

Model children and models for children in Early Mexico. In: Hecht, Tobias (Ed.). Minor omissions: children in Latin American history and society. Madison: University of Wisconsin Press. p.52-71.

Introduction.

Journal of Family History, Ottawa, v.23, n.3, p.223.

Raça, ciência e sociedade.

Rio de Janeiro: Ed. Fiocruz. 
Malvido, Elsa 2004

Malvido, Elsa 1980

Marcílio, Maria Luiza 1998

Marcílio, Maria Luiza 1997

Marcílio, Maria Luiza 1993

Marko, Tamera 2005

Marko, Tamera July 2004

Márquez, Patricio; Joly, Daniel 1986

Martínez Barbosa, Xochitl 1993

Mazumdar, Pauline M.H 1992

Mazzeo, Victoria 1993

Mazzeo, Victoria;

Pollero, Raquel 2005

McCaa, Robert 1996

McGuire, James W.; Frankel, Laura B. 2005

Mead, Karen 2000

Mesa-Lago, Carmelo 1985
Mortalidad infantil y el abandono en años de crisis, en la Casa del Desamor, 1767-1790. Noticias ADEH, Madrid, v.10.

El abandono de los hijos: una forma de control del tamaño de la familia y del trabajo indígena: Tula (1683-1730). Historia Mexicana, México (DF), v.29, n.4, p.521-561.

Etnodemografia da criança abandonada na história do Brasil: séculos 18 e 19. Latin American Population History Bulletin, Minneapolis, v.28, p.2-11.

A Roda dos Expostos e a criança abandonada na história no Brasil, 1726-1950. In: Freitas, Marcos Cezar de (Ed.). História social da infância no Brasil. São Paulo: Cortez. p.51-76.

A Irmandade da Santa Casa de Misericórdia e a assistência à criança abandonada na história do Brasil. In: Marcílio, Maria Luiza (Ed.). Familia, mulher, sexualidade e Igreja na história do Brasil. São Paulo: Loyola. p.149-156.

When they became the nation's children: the raced, classed, and gendered politics of the foundation of pediatrics in Rio de Janeiro, Brazil, 1881-1943. Dissertation (Philosophical Doctor) - University of California, San Diego.

A wet nurse, her masters, a folkhealer, a pediatrician, and two Babies: negotiation of a 'raceless' motherhood ideal and cultural legacies of slavery in 1880 Rio de Janeiro. In: Marko, Tamera; Warren, Adam (Ed.). Women, ethnicity, and medical authority: historical case studies in reproductive health in Latin America. San Diego: Center for Iberian and Latin American Studies/University of California. (CILAS Working Paper, 21.) p.49-77.

A historical overview of the ministries of public health and the medical programs of the social security systems in Latin America. Journal of Public Health Policy, Boston, v.7, p.378-394.

La Casa de Niños Expósitos. In: México. Dirección General de Atención Materno Infantil. La atención materno infantil: apuntes para su historia. México D.F.: Secretaría de Salud. p.147-167. p.55-61.

Eugenics, human genetics and human failings: the Eugenics Society, its source and its critics in Britain. London: Routledge.

Mortalidad infantil en la ciudad de Buenos Aires (1856-1986).

Buenos Aires:Centro Editor de América Latina. (Biblioteca Política Argentina, 440.)

La mortalidad infantil en ambas márgenes del río de la Plata en la primera mitad del siglo XX: ¿dos orillas, dos realidades?. VIII Jornadas Argentinas de Estudios de Población Asociación de Estudios de la Población Argentina (AEPA). Tandil, 12-14 Oct. 2005.

Matrimonio infantil, 'cemithualtin' (familias complejas) y el antiguo pueblo Nahua. Historia Mexicana, México (DF), v.46, n.1, p.3-70.

Mortality decline in Cuba, 1900-1959: patterns, comparisons, and causes. Latin American Research Review, Austin, v.40, n.2, p.83-116.

Beneficent maternalism: Argentine motherhood in comparative perspective, 1880-1920. Journal of Women's History, Baltimore, v.12, n.3, p.120-145.

El desarrollo de la seguridad social en América Latina.

Santiago de Chile: Cepal, Naciones Unidas. 
Milanich, Nara

2004

Milanich, Nara

2002

Miller, Francesca

1991

Milton, Cynthia E. 2004

Minchom, Martin 1994

Miranda, Francisco 1930

Mitchell, Brian R. 2003

Molyneux, Maxine 2001

Moreno, José Luis 2000

Morgan, Lynn M. 1990

Morquio, Luis 1929

Muñoz, Cecilia;

Pachón, Ximena 1991

Oliver Sánchez, Lilia V. 1986

Opas

1948

Ortiz de Montellano, Bernard

1990

Palmer, Steven

2003

Pellegrino, Adela 1997

Pereira, Júnia Sales 2006

Plan de trabajo... 1890

Potthast, Barbara;

Carreras, Sandra 2005
The Casa de Huerfanos and child circulation in late-nineteenth-century Chile. Journal of Social History, Fairfax, v.38, n.2, p.311-340.

Historical perspectives on illegitimacy and illegitimates in Latin America. In: Hecht, Tobias (Ed.). Minor omissions: children in Latin American history and society. Madison: University of Wisconsin Press. p.72-101.

Latin American women and the search for social justice. Hanover (NH):

University Press of New England.

Wandering waifs and abandoned babes: the limits and uses of juvenile welfare in eighteenth-century Audiencia of Quito. Colonial Latin American Review, Abingdon, v.13, n.1, p.103-128.

The people of Quito, 1690-1810: change and unrest in the underclass. Boulder: Westview Press.

The public health department in Mexico City. American Journal of Public Health, Washington (DC), v.20, n.10, p.1125-1128.

International Historical Statistics: the Americas, 1750-2000.

New York: Palgrave Macmillan.

Women's movements in international perspective: Latin America and beyond. New York: Palgrave.

El delgado hilo de la vida: los niños expositos de Buenos Aires, 1779-1823. Revista de Indias, Madrid, v.60, n.220, p.663-685.

International politics and primary health care in Costa Rica.

Social Science and Medicine, Oxford, v.30, n.2, p.211-219.

La higiene escolar en America. Boletín del Instituto Internacional Americano de Protección a la Infancia, Montevideo, v.3, n.1, p.5-16.

La niñez en el siglo XX.

Bogotá: Planeta.

La mortalidad infantil de Guadalajara hacia 1887-1896 analizada por el doctor Miguel Mendoza López. Quipu, Revista Latinoamericana de Historia de las Ciencias y la Tecnología, México (DF), v.3, n.2, p.177-188.

Organización Panamericana de la Salud. Puericultura. Boletín de la Oficina Sanitaria Panamericana, Washington, v.27, n.6, p.557-558.

Aztec medicine, health and nutrition. New Brunswick:

Rutgers University Press.

From popular medicine to medical populism: doctors, healers, and public power in Costa Rica 1800-1940. Durham: Duke University Press. p.145-146.

Caracterización demográfica del Uruguay. Montevideo: Unidad

Multidisciplinaria, Programa de Población/Facultad de Ciencias Sociales/ Universidad de la República.

História da pediatria no Brasil de final do século XIX a meados do século XX. Dissertation (Philosophical Doctor) - Universidade Federal de Minas Gerais, Belo Horizonte.

Plan de trabajo de la Comisión Municipal Encargada de Estudiar las Causas de Mortalidad Infantil. Buenos Aires: s.n.

Entre la familia, la sociedad y el Estado: niños y jovenes en América Latina siglos XIX-XX. Frankfurt: Vervuert. 
Potthast, Barbara;

Scarzanella, Eugenia 2001

Premo, Bianca 2000

Proctor, Robert 1988

Puerto, Alexandra July 2004

Recalde, Hector 1988

Reis, José Roberto Franco mar.-jun. 2000

Reyes Londoño, Jorge Humberto 1997

Rial, Juan 1980

Rizzini, Irene 2002

Rizzini, Irene;

Pilotti, Francisco 1995

Rocha, Heloísa

H. Pimenta 2003

Rodríguez, Sebastián 1906

Rollet, Catherine 1997

Ruggiero, Kristin 1992

Saavedra, Alfredo 1935

Salinas Meza, Rene 1991

Santos-Granero, Fernando
Mujeres y naciones en América Latina: problemas de inclusión y exclusión. Frankfurt: Vervuert Iberoamericana.

Pena y protección: delincuencia juvenil y minoridad legal en Lima Vicerreinal, siglo XVIII. Histórica, Lima, v.24, n.1, p.85-120.

Racial hygiene: medicine under the nazis.

Cambridge: Harvard University Press.

Henequen monoculture, Maya labor, and infant mortality in postrevolutionary Yucatán. In: Marko, Tamera; Warren, Adam (Ed.) Women, ethnicity, and medical authority: historical case studies in reproductive health in Latin America. San Diego: Center for Iberian and Latin American Studies/University of California. (CILAS Working Paper, 21.)

La higiene y el trabajo. v.2. Buenos Aires: Centro Editor de América Latina.

'De pequenino é que se torce o pepino': a infância nos programas eugênicos da Liga Brasileira de Higiene Mental. História Ciências Saúde Manguinhos, Rio de Janeiro, v.7, n.1, p.135-157.

La salud y enfermedades infantiles en Medellín: Clínica Noel, 1924-1932. In: Guerrero, Javier (Ed.). Medicina y salud en la historia de Colombia. Tunja: Universidad Pedagógica y Tecnológica de Colombia. p.163-172.

Población y desarrollo de un pequeño país, Uruguay 1830-1930. Montevideo: CIESU.

The child-saving movement in Brazil: ideology in the late nineteenth and early twentieth centuries. In: Hecht, Tobias (Ed.). Minor omissions: children in Latin American history and society. Madison: University of Wisconsin Press. p.165-180.

A arte de governar crianças: a história das políticas sociais, da legislação e da assistência à infância no Brasil. Montevideo: Instituto Interamericano del Niño.

Educação escolar e higienização da infância.

Caderno Cedes, Campinas, v.23, n.59, p.39-56.

La tuberculosis en las escuelas. La Tuberculosis - Organo de la Liga contra la Tuberculosis en el Uruguay, Montevideo, v.4, n.6, p.152-155.

Le modèle de la goutte de lait dans le monde: diffusion et variantes. In: Musées municipaux de Fécamp. Les biberons du Docteur Dufour. Fécamp: Musées Municipaux de Fécamp. p.111-117.

Honor, maternity and the disciplining of women: infanticide in jate 19th-century Buenos Aires. Hispanic American Historical Review, Pittsburg, v.72, n.3, p.353-373.

Historia del movimiento eugenésico en México. Pasteur: Revista Mensual de Medicina, México (DF), v.1, n.1, p.19-26.

Orphans and family disintegration in Chile: the mortality of abandoned children, 1750-1930. Journal of Family History, Ottawa, v.16, n.3, p.315-29.

Saint Christopher in the Amazon: child sorcery, colonialism, and violence among the Southern arawak. Ethnohistory, Durham, v.49, n.3, p.507-543. 

Sapriza, Gabriela
2002

Sater, William F. 2003

Scarzanella, Eugenia 2003

Scarzanella, Eugenia 2001

Schell, Patience A. 2004

Schneider, William H. 1986

Shein, Max 1986

Skocpol, Theda 1992

Soustelle, Jacques 1970

Sowards, Kathryn A. 1993

Speckman Guerra, Elisa 2005

Stepan, Nancy Leys 1991

Stern, Alexandra 1999

Stern, Alexandra Feb. 1999

Torroella, Mario 1943

Twinam, Ann 1999

Ulloa, Juan J. et al. 1910

Ungerer, Regina

Lúcia Sarmento

2000
La despenalización del aborto a luz de la eugenesia uruguaya (19341938). Revista Fragmentos de Cultura, Goiânia, v.12, n.65.

The politics of public health: smallpox in Chile.

Journal of Latin American Studies, London, v.35, n.3, p.513-543.

'Los pibes' en el Palacio de Ginebra: las investigaciones de la Sociedad de las Naciones sobre la infancia latinoamericana (1925-1939). Estudios Interdisciplinarios de América Latina y el Caribe, Tel Aviv, v.14, n.2, p.5-30.

Proteger a las mujeres y los niños: el internacionalismo humanitario de la Sociedad de las Naciones y las delegadas sudamericanas. In: Potthast, Barbara; Scarzanella, Eugenia (Ed.). Mujeres y naciones en América Latina: problemas de inclusión y exclusión. Frankfurt: Vervuert Iberoamericana. p.205-221.

Nationalizing children through schools and hygiene: porfirian and revolutionary Mexico city. The Americas, Baltimore, v.60, n.4, p.558-587.

Puericulture and the style of French eugenics.

History and Philosophy of the Life Sciences, London, v.8, p.265-277.

El niño precolombino.

Mexico (DF): Villicaña.

Protecting soldiers and mothers: the political origins of social policy in the United States. Cambridge: Harvard University Press.

Daily life of the Aztecs on the Eve of the Spanish conquest.

Palo Alto: Stanford University Press.

Assigning racial labels to the children of interracial marriages in Brazil: patterns in child mortality. Social Science Quarterly, Austin, v.74, n.3, p.631-644.

Infancia es destino: menores delincuentes en la ciudad de México (18841910). In: Agostoni, Claudia; Speckman Guerra, Elisa (Ed.). De normas y transgresiones: enfermedad y crimen en América Latina (1850-1950). México (DF): Instituto de Investigaciones Históricas/Universidad Nacional Autónoma de México. (Historia Moderna y Contamporánea, 43). p.225-253.

The hour of eugenics: race, gender, and nation in Latin America. Ithaca: Cornell University Press.

Responsible mothers and normal children: eugenics, nationalism, and welfare in post-revolutionary Mexico, 1920-1940. Journal of Historical Sociology, Oxford (UK), v.12, n.4, p.369-397.

Unraveling the history of eugenics in Mexico.

The Mendel Newsletter, Philadelphia (PA), n.8.

Alimentación en la primera infancia de niños aborígenes.

Boletín Sociedad Cubana de Pediatría, La Habana, v.15, n.2, p.635-638.

Public lives, private secrets: gender, honor, sexuality, and illegitimacy in colonial Spanish America. Stanford: Stanford University Press.

Report presented by the Delegation of the Republic of Costa Rica. In: Fourth International Sanitary Conference of the American Republics. Transactions.... Washington (DC): Pan American Union. p.138.

Começar de novo: uma revisão histórica sobre a criança e o alojamento conjunto mãe-filho. Rio de Janeiro: Papel Virtual. 
Vargas Olvera, Rogelio 1993

Vejarano, Fernán 1998

Venâncio, Renato Pinto 1995

Venâncio, Renato Pinto; Marcílio, Maria Luiza

Vessuri, Hebe set.-dez. 2001

Viesca Treviño, Carlos 1986

Wadsworth, James E. 1999

Wadsworth, James E.;

Marko, Tamera. 2001

Weindling, Paul 1999

Weindling, Paul 1992

Wood, Charles H.;

Lovell, Peggy A. 1992

Zárate Campos, María Soledad 1999a

Zárate Campos, María Soledad $1999 b$

Zárate Campos, 1996

Zioni, Fabíola Gomes;

Adorno, Rubens de C.F. dez. 1990
De la escuela correccinal a la escuela industrial (1841-1937). In: México. Dirección General de Atención Materno Infantil. La atención materno infantil: apuntes para su historia. México (DF): Secretaría de Salud. p.65-91.

Nacer, casarse y morir: un estudio de demografía histórica. Bogotá: Centro de Investigaciones Sobre Dinámica Social/Universidad Externado de Colombia

O abandono de crianças no Brasil antigo: miséria, ilegitimidade e orfandade. História, São Paulo, v.14, n.153-171.

História social da criança abandonada. Revista Brasileira de História, São Paulo, v.19, n.37, p.313-316. 1999

Enfermería de salud pública, modernización, y cooperación internacional: el proyecto de la Escuela Nacional de Enfermeras, 1936-1950. História, Ciências, Saúde-Manguinhos, Rio de Janeiro, v.8, n.3, p.507-539.

Medicina prehispánica de México: el conocimiento médico de los nahuas. México (DF): Panorama Editorial.

Moncorvo Filho e o problema da infância: modelos institucionais e ideológicos da assistência à infância no Brasil. Revista Brasileira de História, São Paulo, v.19, p.37.

Children of the patria: representations of childhood and welfare state ideologies at the 1922 Rio de Janeiro International Centennial Exposition. The Americas, Baltimore, v.58, n., p.65-90.

International eugenics: Swedish sterilisation in context. Scandinavian Journal of History, Oslo, v.24, p.179-197.

The survival of eugenics in twentieth century Germany. American Journal of Human Genetics, Chicago, v.52, p.643-649.

Racial inequality and child mortality in Brazil. Social Forces, North Carolina, v.70, n.3, p.703-724.

De partera a matrona: los inicios de la profesionalización del cuidado de la madre y de los hijos en Chile, 1870-1920. Revista Colegio de Matronas, Santiago de Chile, v.7, n.2, p.13-18.

Proteger a las madres: origen de un debate público, 1870-1920.

Revista Nomadías, Santiago de Chile, v.1, p.163-182.

Vicious women, virtuous women: the female delinquent and the House of Correction of Santiago. In: Salvatore, Ricardo; Aguirre, Carlos (Ed.). The birth of the penitentiary in Latin America: essays on criminology, prison reform and social control, 1830-1940. Austin: University of Texas Press. p.78-100.

Crescimento e desenvolvimento na prática dos serviços de saúde: revisão histórica do conceito de criança. Revista de Saúde Pública, São Paulo, v.27, n.6, p.472-477. 